\title{
EQUiLIBRIUM
}

Quarterly Journal of Economics and Economic Policy

2015 VOLUME 10 ISSUE 3, September

p-ISSN 1689-765X, e-ISSN 2353-3293

www.economic-policy.pl

Żuchowska, D. (2015). Accession to the Eurozone as Lithuania's Exit Strategy From the Currency Board System. Equilibrium. Quarterly Journal of Economics and Economic Policy, 10(3), pp. 27-43, DOI: http://dx.doi.org/10.12775/ EQUIL.2015.023

Dorota Żuchowska*

College of Social and Media Culture in Toruń, Poland

\section{Accession to the Eurozone as Lithuania's Exit Strategy From the Currency Board System}

JEL Classification: $E 31 ; F 31 ; F 36$

Keywords: Currency Board; Inflation; Euro Adoption; Lithuania

\begin{abstract}
In the years 2004-2014 the Lithuania's exchange rate policy was based on a rigid currency board system. After a period of uncontested success in the fight against inflation in the first decade of the transition and economic growth, entering the ERM II in 2004 and efforts to adopt the euro were treated as an optimal exit strategy from the currency board system. However, the consequences of this exchange rate system in the following years (until 2014) prevented Lithuania from meeting the economic convergence criteria.

The starting point for the research is based on the theoretical analysis of literature studying benefits and risks associated with the use of the currency board system by the monetary authorities. The empirical analysis refers to the case of Lithuania and covers the years 2004-2014. The purpose of this analysis is to look at the effects of the use of the currency board system from the perspective of the convergence criteria of monetary nature and the extent of their implementation in the absence of opportunities for autonomous monetary policy.
\end{abstract}

(C) Copyright Institute of Economic Research \& Polish Economic Society Branch in Toruń Date of submission: March 26, 2015; date of acceptance: June 15, 2015

* Contact: d.zuchowska@wp.pl, College of Social and Media Culture in Toruń, Department of Economic Policy, ul. Św. Józefa 23/35, 87-100 Toruń, Poland 


\section{Introduction}

One of the modern varieties of the rigid exchange rate systems is the currency board system. It was used during the systemic transformation in the Baltic States - Lithuania and Estonia. While the use of the currency board system largely contributed to the stabilisation of the economy and the effective suppression of inflation in the first decade, after the accession to the European Union in 2004 it also began to show the negative consequences of this exchange rate system. In the Baltic States - in contrast to other economies in Central and Eastern Europe - after reaching the macroeconomic stabilisation no changes in the exchange rate system into a more flexible system were introduced. Both in Estonia and Lithuania rapid adoption of the euro was treated as an exit strategy from the currency board system (see: Gulde et al., 2000; Brixiova et al., 2010, p. 222). However, despite the accession of these economies to the ERM II as early as June 2004 , in the subsequent years there were serious problems with meeting the convergence criteria, especially the inflation criterion. In addition, under the impossibility of carrying out an autonomous monetary policy as a result of the global financial crisis, these countries experienced a very deep economic downturn. Finally, Estonia was incorporated into the Eurozone on 1 January 2011, while Lithuania only on 1 January 2015. A particularly interesting case is the Lithuanian economy, which in 2006 ran less than 0.1 percentage point to meet the inflation criterion, and because of the limitations associated with the currency board system this criterion was possible only in 2014.

The purpose of this article is to confront the theoretical risks of a currency board with the experience of Lithuania. The conclusions from the analysis are universal as they permit to describe the consequences of the situation when it is not possible to run an autonomous monetary policy, both in good economic times and in the face of the global financial crisis.

\section{Methodology of the Research}

The starting point for the research is - based on the studies of the specialist literature - the theoretical analysis of the benefits and risks associated with the use of a currency board system in the economy, particularly the consequences of renunciation by the monetary authorities of conducting autonomous monetary policy. 
The empirical analysis refers to the case of Lithuania and covers the years 2004-2014, i.e. the period within the ERM II. The purpose of this analysis is to look at the effects of the use of the currency board system in good economic times and in the crisis conditions through the prism of the extent to which the convergence criteria of the monetary nature were realised. What will also be taken into account is the experience of other economies that used the currency board system in modern times and moved away from the pursuit of such an exchange rate policy. This will enable answering the question whether the risks associated with the use of a currency board system are due to the specific conditions of a given economy or whether they stem from the essence of a rigid exchange rate system.

\section{Benefits and Risks of a Currency Board - Theoretical Analysis}

Currency board (CB) is defined as a monetary institution that provides the exchange of the monetary base only in exchange for foreign currency representing foreign exchange reserves (Enoch \& Gulde, 1998; Williamson, 1995, p. 2). The theoretical basis of the currency board system dates back to the year 1800; it was first introduced in 1849 in the British colony of Mauritius, and then widely used, mainly in the British colonies. It was most common in the 1940s and 1950s but then there was a shift from this exchange rate solution in favour of the independent national currency. Renewed interest in this system appeared in the early 1990s, when the currency board was introduced by the governments of Argentina, Estonia and Lithuania (see more Williamson, 1995, pp. 5-11; Wolf et al, 2008, pp. 7$18)$.

Theoretically, the institution of the currency board can replace the central bank or it may function besides the existing central bank. Foreign exchange reserves held by the CB correspond to $100-110 \%$ of the monetary base and are maintained in the currency which the national currency is linked to in the form of deposits of high liquidity and safety in reputable institutions. Only the currency of a country of high stability and low inflation, which is also the most important trading partner (see Gulde et al., 2000, pp. 5-6), can be selected as a currency anchor. In the currency board system there is a full convertibility of the national currency into the reserve currency, which means that at each request the central bank allows an exchange of the national banknotes and coins into foreign currency at a fixed rate. It does not exercise control over commercial banks and it does not function as the lender of last resort. The central bank cannot finance the 
budget deficit and the monetary authorities are independent of political decisions. A commitment to the long-term use of the CB by appropriate legislation helps to enhance the credibility of the system (compare Hanke, 2002, pp. 204-206). Stronger commitment to maintain the currency board would entail greater benefits from the introduction of this exchange rate solution.

The main advantages of the introduction of the currency board include (see Imam, 2010, p. 20; Gulde et al., 2000, pp. 2-6; Wolf et al., 2008, pp. 2730):

- increased macroeconomic policy discipline and its credibility (i.e. the disciplining effect);

- eliminated exchange rate risk in trade;

- lost ability of the central bank to conduct monetary policy aimed at achieving short-term goals, which is a message to the outside world of the strict observance of the rules;

- imported credible monetary policy from the outside (i.e. credibility effect);

- 'anchored' inflation at the level of the inflation occurring in the country which the currency exchange rate is tied with.

However, alongside the benefits of using a currency board system, related to the possibility of limiting inflation, the use of the exchange rate regime also involves certain risks for inflation trends from the outside. This is because the supply of money in the monetary system is dependent on the money issued by the reserve country (see Antas, 2001; Jakubiak, 2000). The reason for the creation of inflation in the currency board system can also be an increase in the money supply as a result of the influx of foreign capital and development of a positive balance of payments. Sławinski (2007, p. 289) sees renunciation by the monetary authorities of the ability to influence the level of real interest rates as the main source of threats to the currency board system. This is because it means the inability to conduct monetary policy, which cannot counteract the pro-cyclical changes in real interest rates, and could lead to a rapid accumulation of imbalances in the economy. In the event of any adverse external shocks the high rigidity of prices and wages may be associated with a decline in the competitiveness of the economy and hinder economic growth. In the currency board system automatic control of the money supply by matching at the level of the interest rate simultaneously causes significant fluctuations in interest rates. It is particularly fierce in a situation of declining confidence of foreign investors and capital flight. A developed and strong banking sector, which is well able to cope with significant fluctuations in interest rates (Enoch \& Gulde, 
1998) is mentioned as a condition for the effective application of the currency board, and thus achieving the goal of curbing inflation.

\section{Currency Board System in Lithuania Before Entering the ERM II - Historical Overview}

In Lithuania the currency board (CB) system was introduced on 1 April 1994, after almost two years of the floating exchange rate regime. The Lithuanian litas (LTL) was pegged to the US dollar in the relation of 4 LTL $=1$ USD (Alonso-Gamo et al., 2002, p. 5). The dollar served as the reserve currency since January 1994. Initially, Lithuania based its currency board model on the Estonian system. Two departments were part of the central bank: Foreign Department and Monetary Policy Department. The primary objective of the Bank of Lithuania, determined in the legislature, was to achieve monetary stability. The central bank was responsible for the monetary policy of the country, managed the foreign currency reserves, as well as monitored the use of the currency board system. In addition, it was responsible for the banking supervision. It could make loans to commercial banks and other financial institutions at risk of losing liquidity (the credit value, however, could not exceed $60 \%$ of the commitments of the assisted institution) (Bank of Lithuania, 1994). The change in the nominal exchange rate in Lithuania by the central bank could take place after the consultation with the government, and only in the case of extraordinary circumstances threatening the stability of the economy (Jakubiak, 2000, p. 10). This meant less restrictive protection of the currency board system in comparison with the countries in which the change is subject to the consent of the Parliament. The level of foreign currency reserves provided 100\% coverage of the monetary base and liquid liabilities of the central bank. The scope of the obligations of the central bank, however, did not include loans, mainly from the International Monetary Fund.

The prerequisite for the decision to introduce the CB system in Lithuania was to quickly build full confidence of its own citizens and foreign investors in the domestic currency. The litas, pegged against the US dollar, also acted as an anti-inflationary anchor. The use of the CB system was designed to communicate the financial markets the lack of experience in the conduct of monetary policy will be compensated for by the observance of strict rules to ensure price stability. In 1997, after the crisis of the banking system in Lithuania, there was an attempt to change the currency board system into a more flexible exchange rate system before joining the ERM II. In 1998, the Bank of Lithuania became a lender of last resort, but finally 
in 2000 the Bank officially resigned from conducting open market operations. The remaining strategic objective of the bank was to take care of price stability. In October of 1999, in connection with the growing ties between the Lithuanian economy and the European Union as well as the future Lithuania's accession to the Eurozone, the decision was taken to change the reserve currency from the dollar to the euro starting from February 2002 (see more Alonso-Gamo et al., 2002, pp. 4-11). The effect of this action was the phenomenon of 'dedollaring' of the economy in 20012002. After applying these changes, the dollar weakened significantly in relation to the national currency, although it was officially announced that the litas would not be devalued or revalued against the new currency anchor. Finally, the course was set at 1 euro $=3.4528$ litas.

Along with the use of the CB system Lithuania enjoyed a lot of success in reducing inflation. Average annual inflation rate gradually declined: from $39.66 \%$ in 1994 to $24.62 \%$ in 1995 to $8.88 \%$ in 1996 and $5.07 \%$ in 1997. Even during the turmoil in global financial markets in the late 1990s (effects of the Czech, Asian and Russian crises), despite small fluctuations in individual months, the inflation rate persisted at a very low level - the average inflation rate was $0.75 \%$ in 1998 and $0.99 \%$ in 1999. In 2000-2003, the average annual inflation rate did not exceed $1.36 \%$, and the country even experienced a temporary deflation (-1.13\% in 2002). The fixed exchange rate and rapid liberalisation of capital flows contributed to the development of foreign trade and economic growth. Since 2000, Lithuania entered the path of rapid economic growth, recording the annual changes in the GDP volume from $4.23 \%$ in 2000 to as much as $10.25 \%$ in 2003 . At the same time the exchange rate policy forced the authorities to conduct prudent fiscal policy (Sławiński, 2007, p. 280). In the first decade of using the currency board system, thus, many benefits revealed, especially in terms of suppressing inflation. In 1999-2004, the average annual inflation rate was the lowest among the economies of Central and Eastern Europe. However, the string of economic success of Lithuania - referred to as one of the "Baltic Tigers" - after joining the European Union in 2004, and later to the ERM II, symptoms began to appear indicating the existence of significant limitations associated with the use of such a restrictive exchange rate. 


\section{Monetary Convergence in Lithuania in the Conditions of the Currency Board}

In connection with the strategy adopted by the monetary authorities of Lithuania - from the currency board to the euro (see Gulde et al., 2000, pp. 16-18), on 28 June 2004 the litas was included in the ERM II. Lithuania maintained its commitment to the use of the currency board and unchanged litas pegged to the euro. So restrictive exchange rate policy thus guaranteed meeting the first of the monetary criteria - exchange rate stability after two years in the ERM II, which was in June 2006. At the same time, however, it had a significant impact on the implementation of the other two monetary criteria - of price stability and of convergence of interest rates. It should be noted that the experience of other economies of Central and Eastern Europe showed a clear imperfection of the convergence criteria for the countries aspiring to join the euro zone, especially the inconsistency of the exchange rate and inflation criteria (see more Żuchowska, 2011, pp. 8-25).

The price stability criterion means that the rate of inflation, observed over a period of one year before the examination, does not exceed the inflation of the three EU member states with the most stable prices by more than 1.5 percentage points. Figure 1 shows the degree of meeting this criterion by Lithuania in the periods preceding the publication of the consecutive convergence reports. It is clear that this criterion was met in October 2004, that is, in the initial period in the ERM II, and then only in June 2014. In other reference periods the differences ranged from 1 to as much as 4.2 percentage points.

Figure 1. Meeting price stability criterion by Lithuania

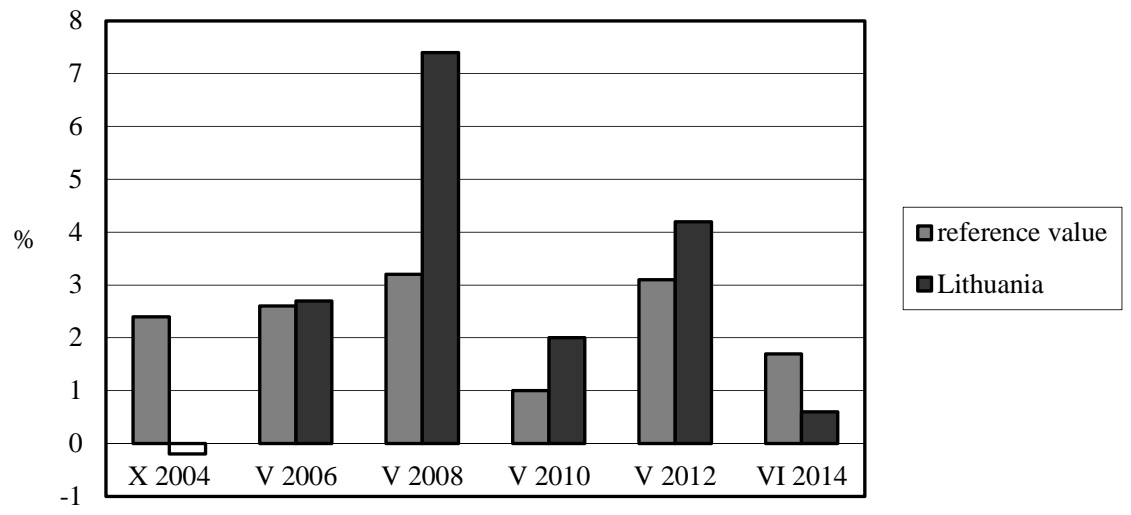

Source: own calculations based on: ECB, 2004, 2006, 2008, 2010, 2012, 2014. 
Figure 2. HICP in Lithuania against the Euro area average between January 2004 and November 2014 (monthly data y/y)

HICP

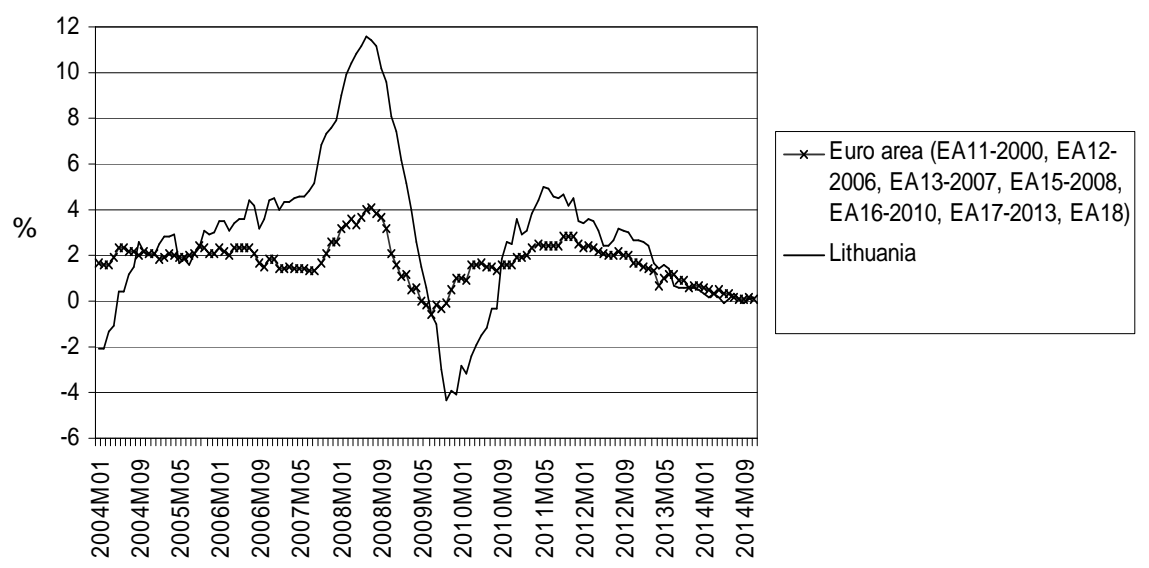

Source: Eurostat (27.12.2014).

The analysis of the historical data shows that the inflation in consumer prices in Lithuania remained at a relatively low level until mid-2006 (see Fig. 2). However, the problems of the rising inflation started already in May 2004 and were associated with the accession shock. In 2006 Lithuania minimally did not meet the criterion of the price stability and did not enter the euro area (12-month average rate of HICP inflation was $2.7 \%$, which was just above the reference value stipulated in the Treaty, which was $2.6 \%$ ). What should be noted while assessing the level of inflation in Lithuania during this period are the restrictions on the formation of the money supply by the central bank resulting from the application of the $\mathrm{CB}$. The interest rates in the country were in fact related to the interest rates of the euro area, and the rigid link of the litas to the euro entailed a limited ability to respond to the short-term fluctuations in the inflation rate (Baran, 2007, p. 42). Threats of rising inflation in Lithuania, which were then pointed out, include: harmonisation of excise duty to the EU level, dynamic output growth fueled by strong credit growth and low interest rates, as well as emerging bottlenecks in the labour market, which carry a risk of increasing unit labour costs and - consequently - domestic prices (ECB, 2006, p. 20). The HICP inflation continued to rise sharply in 2007, reaching a record level of $11.6 \%$ in June 2008. At the same time the Lithuanian economy showed growing signs of overheating and emerging significant imbalances. In 2004-2006 the real GDP growth remained at a level above 7\% and 
reached $9.8 \%$ in 2007 (see Fig. 3). It was mainly stimulated by the high domestic demand. While the economy rapidly hastened, after joining the EU there was an outflow of human resources, so unemployment fell to the historically low levels; as a result, unit labour costs increased significantly. The domestic demand boom ended abruptly in 2008, which was due to the weakening external demand as a result of the outbreak of the global financial crisis. Just as in other CEE countries, due to the crisis of confidence there was a rapid outflow of foreign capital from Lithuania. In view of the fact that the currency board system does not allow to run an autonomous monetary policy, the monetary authorities could not actively resist the deteriorating economic situation of the country (see more Purfield, 2010). For most of 2008 Lithuania - as the only Baltic economy - stood firm against a strong economic slowdown, but in the fourth quarter the GDP decreased by $2.2 \% \mathrm{y} / \mathrm{y}$. In 2009, the GDP declined at a record high level of $14.8 \% \mathrm{y} / \mathrm{y}$ (see Fig. 3). The economic downturn during the global crisis caused a rapid disinflation process in the Lithuanian economy, which turned up into a periodic deflation. In the second half of 2008 there was a downward trend in inflation (see Fig. 2). In 2009, the HICP inflation fell sharply, with the June level of only $0.6 \%$ (y/y), while the period from July 2009 to August 2010 was characterised by a negative growth rate of consumer prices (deflation ranged from $-0.3 \%$ to $-4.3 \%$ (y/y). This allowed Lithuania to regain price competitiveness of its economy. As noted in the Convergence Report of May 2010, such a situation in the field of inflation should be analised against the background of a strong reduction in domestic spending and reduction of the price dynamics shaped on the global markets (ECB, 2010, p. 46). The return of the GDP growth was associated with an increase in the inflation process in September 2010. The monthly inflation (y/y) increased steadily, in May 2011 reaching the level of 5\% and then keeping up at a level above 4\% until November 2011 (see Fig. 2). This was also associated with the increases in the global food and energy prices (ECB, 2012, p. 83). In 2012, the inflation rate fluctuated around 2.4-3.6\%. As a result of the favourable changes in the global commodity prices as well as a decline in food and administered prices, the downward trend in inflation continued in 2013: it fell from $2.6 \%$ in January to just $0.5 \%$ in December. By 2014, the ratio of consumer prices fluctuated around zero (see Fig. 2). The dynamics of inflation remained at a very low level; temporary deflation was also reported. In contrast, during the reference period - from May 2013 till April 2014 - the 12-month average rate of the HICP inflation in Lithuania was $0.6 \%$, which was significantly lower than the $1.7 \%$ reference value for the criterion on price stability (ECB, 2014, pp. 83-84). After 10 years in the exchange rate mechanism of ERM II Lithuania met the inflation criterion. 
Figure 3. Dynamics of the GDP volume in Lithuania: 2004-2013

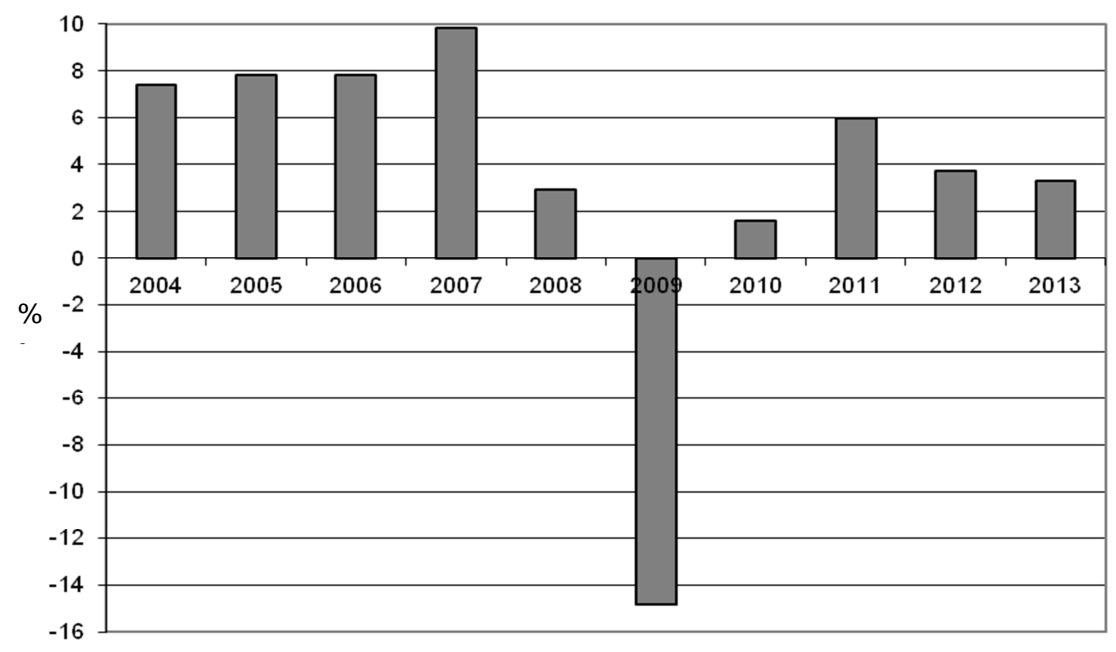

Source: Eurostat (25.12.2014).

The criterion for the convergence of interest rates means that within one year before the examination the Member State had an average nominal long-term interest rate that does not exceed by more than 2 percentage points that of the three EU member states with the most stable prices. As shown in Figure 4, Lithuania met this criterion, with the exception of the reference period after the global financial crisis from April 2009 to March 2010 , when the long-term interest rate was above the reference value by 6.1 percentage points. This was due to the turmoil in the global financial markets, a downgrade of the country and a decrease in liquidity resources (ECB, 2010, p. 47). Also in the field of meeting this monetary criterion there revealed negative consequences of the currency board. When economic growth fell below the potential rate, the monetary authorities of Lithuania could not lower the short-term interest rates to counteract their pro-cyclical changes and reduce the risk of recession. What is more, the more the pace of economic growth got reduced, the more the risk of default of domestic enterprises grew. There was an increase in the long-term interest rates and the likelihood of a recession was growing. These consequences were especially pronounced during the global financial crisis (see Fig. 5). While between January 2004 and August 2008 the differences in the long-term interest rates did not exceed 1 percentage point, in the following months they increased to more than 5 percentage points in December 2008, and then exceeded 10 percentage points until November 2009 (long-term nominal interest rates in Lithuania were then as high as $14.5 \%$ ). At the end 
of 2010 , the nominal interest rate stood at $5.15 \%$, which was slightly lower than before the onset of the turmoil in the global financial markets. In contrast, the differences between the Lithuanian long-term interest rate and the average for the euro area ranged only from 0.41 to 1.31 percentage points from January 2011 to the end of 2014 (see Fig. 5).

Figure 4. Meeting the criterion of the interest rates convergence by Lithuania

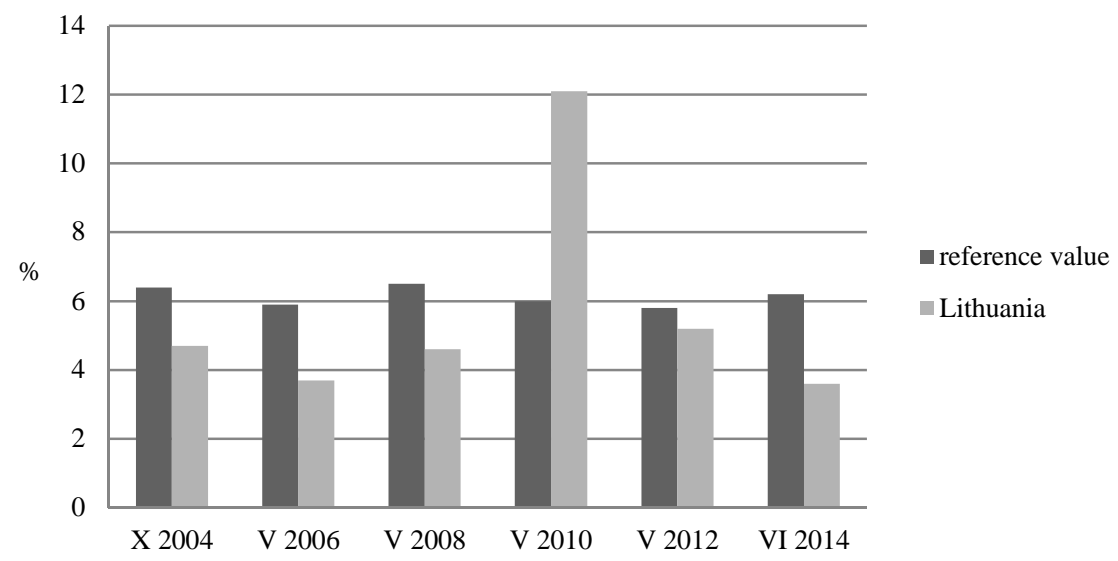

Source: own calculations based on: ECB, 2004, 2006, 2008, 2010, 2012, 2014.

Figure 5. Nominal long-term interest rates in Lithuania against the euro area average

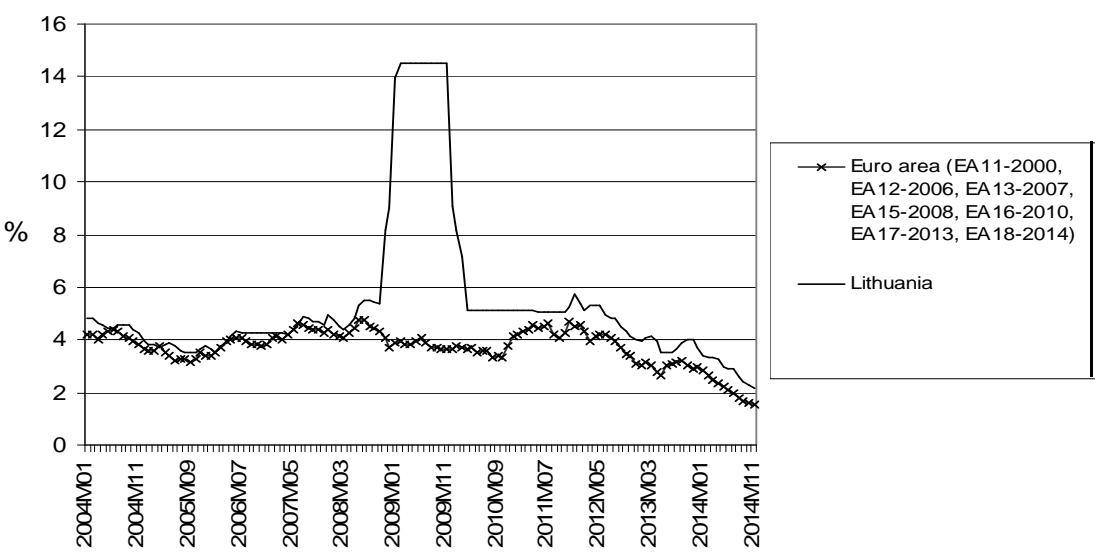

Source: Eurostat (25.12.2014). 
After the period of success in the fight against inflation through a currency board system, serious problems arose in the Lithuanian economy from the excessive use of this exchange rate solution. The case of Lithuania showed that the country took the risk unnecessarily, just after the defeat of inflation. Such a restrictive policy led to a significant deterioration in the trade balance and current account balance in this country. The severity of the inflation process in the first years of the participation in the ERM II prevented the Lithuanian economy from a quick meeting of the inflation criterion and by the adoption of the euro - benefitting from a safe exit strategy. At the same time it deprived Lithuania of tools for a flexible response to the economic situation, which was particularly acute during the global financial crisis. The slowdown in inflation was recorded only during a deep economic recession. The inflation criterion and all the other convergence criteria were met only in the conditions of favourable changes in the world commodity prices and a decline in the food and administered prices between May 2013 and April 2014 (see Table in Appendix). On 1 January 2015 Lithuania was the last of the Baltic economies incorporated into the euro zone. However, in a monetary union, similarly to the terms of the currency board system, the monetary authorities will not be able to pursue independent monetary policy and thus the permanent maintenance of low inflation in Lithuania can be difficult due to the continuation of the process of economic convergence (convergence of incomes and prices).

\section{Lessons From the Experience of Argentina and Estonia}

The focus of this section is the experience of the economies which applied the currency board system since the early 1990, and then moved away from this restrictive foreign exchange solutions, i.e. Argentina (currency board in 1991-2001) and Estonia (currency board in 1992-2010).

The use of the currency board in Argentina and establishment of a fixed exchange rate against the US dollar, after unsuccessful attempts of introducing consecutive stabilisation programs in the 1980s and the loss of credibility of the monetary policy, brought success in the form of a permanent elimination of high inflation, which had been oppressing the country for decades. Additionally, the banking and public sectors were reformed. In a short time, Argentina transformed from a country with a high degree of regulation and protectionism into a liberal market economy (SotomskaKrzystofik, 2003, pp. 48-49). However, the cost of this solution proved to be very high - the economy became vulnerable to external shocks. In the 1990s the economic growth was twice halted as a result of external factors. 
In 1995, the currency crisis in Mexico led Argentina to a currency crisis (due to the outflow of foreign capital), and the recession - the GDP fell by $2.8 \%$. The country managed to survive the crisis with the help of the International Monetary Fund and in 1997 an economic growth of $8.1 \%$ was recorded. However, the effects of the strong devaluation of the Brazilian real in 1999 (a decrease by 40\% in relation to the US dollar) were much more severe for the Argentine economy and led to a long-term economic recession. The fall in the GDP began in 1999; it was 3.3\% and lasted until 2002, when the Argentine economy contracted by $10.9 \%$ (IMF, WEO 2014). In the context of the currency board system, the monetary authorities did not have the opportunity to carry out the devaluation of the peso or lowering interest rates in order to stimulate economic growth. There was a loss of price competitiveness of the economy, the deterioration of the balance of trade and growth of external imbalance. In 1999-2001 Argentina also recorded deflation. After the initial successes, the currency board system itself became a cause of the erosion of the creditworthiness of Argentina. The investors showed rising concerns about how the monetary authorities - unable to conduct an autonomous monetary policy - would cope with the rising external debt (Sławiński, 2001, pp. 57-67). At the beginning of December 2001, there was an escalation of the crisis - the deposits were completely frozen, foreign exchange reserves fell to 14.5 billion UDS (from 32.2 billion in 1999), and the government suspended the foreign debt service. As an exit strategy from the currency board system Argentina adopted a gradual transition to a floating exchange rate system. Initially a dual exchange rate system was introduced - in the settlements of foreign trade and capital flows the official parity was adopted by performing $29 \%$ devaluation, and in the remaining transactions the market rate was in force. The government was forced to intervene in order to prevent the deep depreciation of the peso against the US dollar. It was not able, however, to prevent it, even after the official introduction of the floating exchange rate system (Torre et al., 2003, pp. 20-21). As a result, the Argentine economy suffered the high cost of the application of the currency board.

Estonia's experience with the currency board system was very similar to that of Lithuania. In assessing the effectiveness of the currency board in Estonia in the 1990s we are definitely entitled to the conclusion that during this period the system performed its function well and - by a significant reduction of the inflation rate - contributed to control hyperinflation and achieve financial stability in the economy. In annual terms, in 1999 the inflation rate reached the lowest level (3.29\%) since the introduction of the currency board system. Serious problems with inflation emerged in May 2004, after joining the European Union, and then the ERM II (see more 
Brixiova et al., 2010, pp. 204-205). In the coming years this prevented Estonia from meeting the inflation criterion in a time when all the other convergence criteria were met. One reason for the creation of inflation in the currency board system is an increase in the money supply as a result of the inflow of foreign capital. It was also influenced by increased lending in foreign currencies observed in Estonia after the accession to the European Union. This was due to the lack of exchange rate risk in the conditions of the currency board and constant persistence of lower interest rates in the euro area. In 2004 credits for the private sector accounted for $63.1 \%$ of GDP, and in 2006 for $86 \%$ of the GDP. This resulted in an increase in the foreign debt of Estonian banks. With a disturbingly low level of reserve assets (at the end of 2006, the state of the Estonian official reserves amounted only to $45 \%$ of the short-term foreign debt, which is the level of security), and a high level of deficit in the current account, it constituted serious threat symptoms to the economic balance of the country. In the period when the economic growth rate exceeded the potential rate, the monetary authorities of Estonia were unable to raise interest rates in order to reduce the risk of inflation. Furthermore, the increase in inflation caused a decrease in real interest rates, which further intensified the economic expansion. However, in the situation of the recent financial crisis and economic downturn, which Estonia had to deal with, the monetary authorities of the country were deprived of the possibility of lowering interest rates to reduce the risk of recession. Therefore, the economic collapse occurring in Estonia from the third quarter of 2008 to the first quarter of 2010 was largely compounded by limitations of the monetary policy related to the use of the currency board system. The Estonian economy experienced the deepest economic crisis since the early 1990s. The decrease in the GDP volume reached more than $15 \%$ in the first, second and third quarters of 2009.

One of the most important consequences of the crisis - as it turned out, paradoxically positive for Estonia - was the decline in inflation rates. In Estonia, which had a two-digit rate of inflation before the crisis, i.e. one of the highest in the region, as a result of the global economic downturn observed a rapid disinflation process, sometimes turning into deflation. The drop in the general price level in Estonia continued from May 2009 to February 2010 , which enabled the country to meet the criterion of price stability. Meeting this convergence criteria, which could not have been achieved in a period of high economic growth, was only possible due to the deep economic slump (Żuchowska, 2011, pp. 23-25). The situation of the public finances in Estonia was highly stable and despite a significant decline in the economic activity during the global crisis, the country had the lowest level of domestic debt of the agencies of the central and local governments 
throughout the EU. The public finance discipline enabled Estonia to meet the remaining economic convergence criteria in 2010.

\section{Conclusions}

The conducted analysis enabled to draw the following conclusions.

Firstly, the experience of the analysed economies show that the currency board system is effective in the early years of its use, helping to control hyperinflation and stabilising the economy. In the longer run, however, it turns out to be inefficient. This is related to the problem of time inconsistency, i.e. the solutions which are optimal in a given time, at a certain moment become a source of serious problems themselves in the economy.

Secondly, all the analysed economies suffered the risks associated with the use of a currency board system, as indicated in the theory. Thus, these concerns do not arise from the specific conditions of the economy, but the essence of the solution of the rigid exchange rate.

Thirdly, as shown in the analysis of the case studies, the biggest cost of the implementation of the currency board system is losing the ability to run an autonomous monetary policy, which allows the central bank to act counter-cyclically. This is a disadvantage in both good times and in the times of the GDP drop. In the case of external shocks it prevents the recovery of the competitiveness of the economy through its impact on the level of real interest rates. It is because in the conditions of a rigid exchange rate regime, it is not possible to adjust the side of the exchange rate, so costly adjustment on the side of the labour market and GDP follow.

Fourthly, the experience of Argentina and the Baltic states have shown that the adopted exit strategies from a currency board system were very expensive. Argentina suffered a very high cost of floating exchange rate. Lithuania and Estonia took the risk of the transition from the currency board to the monetary union, without the introduction of more flexible intermediate exchange rate solutions. These economies had serious problems with meeting the convergence criteria, especially the inflation criterion, the source of which was the currency board system. 


\section{References}

Antas Ł. (2001). Systemy izby walutowej. Korzyści i zagrożenia dla krajów rozwijających się. Materiaty i Studia NBP, 133.

Alonso-Gamo P., Fabrizio S., Kramarenko V., \& Wang Q. (2002). Lithuania: History and Future of the Currency Board Arrangement. IMF Working Paper, 02(127).

Bank of Lithuania (1994). Law on the Bank of Lithuania, 12.01.1994, Retrieved form http://www.lb.lt/ (4.06.2009).

Baran K. (2007). Kryterium inflacyjne w rozszerzonej Europie - podsumowanie dyskusji na temat Litwy. Bank $i$ Kredyt, 6.

Brixiova Z., Morgan M. H., \& Wörgötten A. (2010). On The Road to Euro: How Synchronized Is Estonia with the Euro Zone?. European Journal of Comparative Economics, 7(1).

ECB (2004). Convergence Report, European Central Bank, October.

ECB (2006). Convergence Report, European Central Bank, May

ECB (2008). Convergence Report, European Central Bank, May.

ECB (2010). Convergence Report, European Central Bank, May.

ECB (2012). Convergence Report, European Central Bank, May.

ECB (2014). Convergence Report, European Central Bank, June.

Enoch C. \& Gulde A-M. (1998). Are Currency Board a Cure for All Monetary Problems?. Finance and Development, 35(4).

Eurostat, Retrieved form http://ec.europa.eu/eurostat/data/database (30.12.2014).

Ghosh A. R. (1998). Currency Boards: The Ultimate Fix?. IMF Working Paper No. 98/8, http://dx.doi.org/10.5089/9781451927955.001.

Gulde A-M., Kähkönen J. \& Keller P. (2000). Pros and Cons Currency Board Arrangements in the Lead-up to EU Accession and Participation in the Euro Zone, IMF Policy Discussion Paper, 00(1).

Hanke S. (2002). On dollarization and currency boards: Error and deception. Journal of Policy Reform, 5(4), http://dx.doi.org/10.1080/1384128032000096814.

Imam P. A. (2010). Exchange Rate Choices of Microstates, IMF Working Paper, 10(12), http://dx.doi.org/10.5089/9781451962000.001.

IMF, World Economic Outlook Database. Retrieved form http://www.imf.org/external/pubs/ft/weo/2014/02/weodata/index.aspx28.12.201 4 (28.12.2014).

Jakubiak M. (2000). Design and Operation of Existing Currency Board Arrangements, CASE, Warszawa.

Purfield C. \& Rosenberg Ch. B (2010). Adjustment Under a Currency Peg : Estonia, Latvia and Lithuania During the Global Financial Crisis 2008-09, IMF Working Paper, 10(213). http://dx.doi.org/10.5089/9781455205448.001.

Sławiński A. (2001). Argentyna. In: Małecki W., Sławiński A., Piasecki R., Żuławska U., Kryzysy walutowe. Warszawa: PWN.

Sławiński A. (2007). Ryzyko utraty kontroli nad wysokościa realnej stopy procentowej $w$ systemie izby walutowej. In B. Polszakiewicz \& J. Boehlke (Eds.). Wtasność i kontrola w teorii i praktyce. Toruń: Wydawnictwo UMK. 
Sotomska-Krzysztofik P. (2003). Utworzenie i upadek izby walutowej w Argentynie. Bank i Kredyt, 2.

Torre A., Yeyati E. L., \& Schmukler S. L. (2003). Living and Dying with Hard Pegs: The Rise and Fall of Argentina's Currency Board. Policy Research Working Paper, 2980, http://dx.doi.org/10.1596/1813-9450-2980.

Williamson J. (1995). What Role for Currency Boards? Policy Analyses in International Economics. Washington: Institute for International Economics.

Wolf H. C., Ghosh A. R., Berger H., \& Gulde A-Marie (2008). Currency Boards in Retrospect and Prospect, Massachusetts Institute of Technology, http://dx.doi.org/10.7551/mitpress/9780262232654.003.0001.

Żuchowska D. (2011). Polityka kursowa a inflacja procesie integracji walutowej Słowenii, Słowacji i Estonii ze strefą euro. Oeconomia Copernicana, 2(1), DOI: http://dx.doi.org/10.12775/OeC.2011.001.

\section{Appendix}

Table 1. Meeting the convergence criteria by Lithuania

\begin{tabular}{|c|c|c|c|}
\hline Criterion & $\begin{array}{l}\text { Date of the conver- } \\
\text { gence report }\end{array}$ & Reference value & Lithuania \\
\hline \multirow{6}{*}{$\begin{array}{l}\text { Inflation rate } \\
\text { (HICP) (\%) }\end{array}$} & X 2004 & 2.4 & -0.2 \\
\hline & V 2006 & $2.6^{*}$ & $2.7 *$ \\
\hline & V 2008 & $3.2^{*}$ & 7.4* \\
\hline & V 2010 & $1.0^{*}$ & $2.0^{*}$ \\
\hline & V 2012 & $3.1^{*}$ & $4.2^{*}$ \\
\hline & VI 2014 & 1.7 & 0.6 \\
\hline \multirow{6}{*}{$\begin{array}{l}\text { Long-term interest } \\
\text { rates }(\%)\end{array}$} & X 2004 & 6.4 & 4.7 \\
\hline & V 2006 & 5.9 & 3.7 \\
\hline & V 2008 & 6.5 & 4.6 \\
\hline & V 2010 & $6.0^{*}$ & $12.1^{*}$ \\
\hline & V 2012 & 5.8 & 5.2 \\
\hline & VI 2014 & 6.2 & 3.6 \\
\hline \multirow{6}{*}{$\begin{array}{l}\text { Budgetary situa- } \\
\text { tion } \\
\text { (\% of GDP): } \\
\text { deficit (-), surplus } \\
(+)\end{array}$} & X 2004 & -3.0 & -2.6 \\
\hline & V 2006 & -3.0 & -0.6 \\
\hline & V 2008 & -3.0 & -1.7 \\
\hline & V 2010 & $-3.0^{*}$ & $-8.6^{*}$ \\
\hline & V 2012 & -3.0 & -3.2 \\
\hline & VI 2014 & -3.0 & -2.1 \\
\hline \multirow{6}{*}{$\begin{array}{l}\text { Public debt } \\
\text { (\% GDP) }\end{array}$} & X 2004 & 60.0 & 21.4 \\
\hline & V 2006 & 60.0 & 18.9 \\
\hline & V 2008 & 60.0 & 17.0 \\
\hline & V 2010 & 60.0 & 38.6 \\
\hline & V 2012 & 60.0 & 40.4 \\
\hline & VI 2014 & 60.0 & 41.8 \\
\hline $\begin{array}{l}\text { Stability of the } \\
\text { rate }\end{array}$ & & $\begin{array}{l}\text { At least two years of the ERM } \\
\text { II; No devaluation to the euro }\end{array}$ & $\begin{array}{c}\text { ERM II since } \\
28.06 .2004\end{array}$ \\
\hline
\end{tabular}

* unmet criterion

Source: own calculations based on: ECB, 2004, 2006, 2008, 2010, 2012, 2014. 

